\title{
Biopesticidal effect of leaf extract of neem (Azadirachta indica A. Juss) on growth parameters and diseases of tomato
}

\author{
Gayatri Nahak and Rajani Kanta Sahu* \\ KIIT School of Biotechnology, KIIT University, Bhubaneswar-751024 (Odisha), INDIA \\ *Corresponding author. E-mail: sahurajani.sahu@gmail.com
}

Received: February 2, 2015; Revised received: April 30, 2015; Accepted: June 15, 2015

\begin{abstract}
This paper investigates the potential use of neem (Azadirachta indica A. Juss) aqueous leaf extract on the growth, yield and disease control of a common vegetable plant tomato (Solanum lycopersicum L.). The neem extract increased shoot height, number of branches, number of leaves, number of buds, number of flowers and number of fruits of tomato plant over controls in different treatments. Numbers of diseases were calculated as percentage and disease/plant. The percentage of reduction of disease was calculated after the spray of neem extract on plants. Neem extract was found effectively in controlling canker $(50.32 \%)$, early blight $(55.12 \%)$, wilt $(59.45 \%)$, leaf spot $(55.48 \%)$, fruit spot $(41.93 \%)$, blossom end rot $(40.86 \%)$ and sun scald $(25.61 \%)$ in comparison to controls under field condition. Thus, biopesticides can contribute in reducing use of chemical pesticides and subsequently minimize its hazards to the environment and human health.
\end{abstract}

Keywords: Biopesticide, Diseases, Growth parameters, Neem extract, Tomato

\section{INTRODUCTION}

Tomato (Solanum lycopersicum L.) is the second most important vegetable crop in the world because of its special nutritive value. It is one of the most versatile vegetable with wide usage in Indian culinary tradition which is consumed as a fresh vegetable, in ketchup, as a puree, and in many other forms. One of the main constraints to tomato cultivation is damage caused by pathogens, including viruses, bacteria, nematodes and fungi, which cause severe losses in production worldwide. Major fungal diseases affecting tomato production are late blight, early blight, septoria leaf spot, fusarium wilt, and verticillium wilt, corky root rot, damping-off, leaf mold and powdery mildew (Panthee and Chen, 2010). Controlling of plant diseases mainly depend on fungicides treatments (El-Mougy et al., 2004; Rauf, 2004). However, fungicidal applications cause hazards to human health and increase environmental pollution. Therefore, alternatives, eco-friendly approach treatments for control of plant diseases are needed (Abd -El-Kareem, 2007; Rojo et al., 2007; Mandal et al., 2009). Biological control methods are being increasingly used in agriculture as an alternative to chemical fungicides to control diseases caused by fungal plant pathogens. Recently, there have been many reports stated that some plant extracts and safe chemicals become a necessary to control many diseases of vegetable plants (Aba AlKhail, 2005; bogharsa et al., 2006; Deepak et al., 2005; Deepak et al., 2007; Mandal et al., 2009).

The Neem tree (Azadirachta indica A. Juss) has been known as the wonder tree for centuries in the Indian known as the wonder tree for centuries in the Indian subcontinent. It has become important in the global context today because it offers answers to the major concerns facing mankind. It has many uses; the most important use for neem products is to fight against crop pests and diseases without any harmful effects on environment (Abbasi et al., 2003; Akhtar and Mahmood, 1995; Vir and Sharma, 1985; Amadioha, 2000; Dubey et al., 2009; Gajalakshmi and Abbasi, 2004). Neem as a bio-control agent is used for centuries in Asia as a potential antifungal agent (Chaturvedi et al., 2003). Several studies have pointed out the potential of neem (A. indica) tree to control plant pathogenic fungi that could be listed it as top fungicide and harmless bio control agent (Abbasi et al., 2003; Akhtar and Mahmood, 1995; Amadioha, 2000; Dubey et al., 2009). Large number of studies has been undertaken in the laboratory against the causal organism affecting the tomato plant. However the effectiveness of the neem extracts on individual crops in different agro-climatic zones and cultivars in field condition have not been investigated much. Hence the objective of the study was to determine to efficacy of aqueous leaf extract of neem for controlling some important diseases like canker, early blight, leaf spot, fruit spot, blossom end rot, wilt and sun scald as well as its effect on growth and yield of tomato plant.

\section{MATERIALS AND METHODS}

Preparation of experimental plots and plantation: The grasses and weeds of experimental plot were removed and the land ploughed to a depth of $15-30 \mathrm{~cm}$ and several holes with the dimension of $30 \times 30 \times 30 \mathrm{~cm}$ 
were made every 150 inches interval. In each hole, required amount of cow-dung and organic fertilizer at the rate of $6-12 \mathrm{t} / \mathrm{ha}$ was applied. Optimum spacing $90 \times 60 \mathrm{~cm}$ with one plant/hill was maintained. About 10 days old tomato seedlings were planted.

Preparation of aqueous neem extract: Hundred grams from each of the dried, powdered plant sample were weighed and were mixed in $1000 \mathrm{ml}$ distilled water. Then the solution was boiled, cooled and filtered through the cheese cloths followed by filtration by the Whattman No-1 filter paper. Then filtrate was kept under normal room temperature and sprayed on the plants on a weekly basis from $15^{\text {th }}$ day onwards.

Growth, yield and disease parameters: Morphological measurements of tomato plants (Solanum lycopersicum L.) were taken during 10-120 days with 10 days intervals after transplantation till harvest time. The growth parameters were taken into consideration and they are as follows: shoot height, number of leaves, number of buds, number of flowers and number of fruits. The percentage of infection (Canker, Early blight, Wilt, Leaf spot, Fruit spot, Blossom end rot and Sun scald) were investigated after 4 weeks of transplantation. Numbers of diseases were calculated as (\%) and diseases/plant.

Preparation of crude extract: The collected leaves were shade dried under normal environmental condition and then ground into uniform powder using Thomas-Wiley machine. The powdered neem leaves $(50 \mathrm{~g})$ were extracted with distilled water by using Soxhlet extraction apparatus for 10-12 hrs. Then collected solutions were filtered through Whattman No-1 filer paper. The extracts were evaporated to dryness under reduced pressure at $90^{\circ} \mathrm{C}$ by Rotary vacuum evaporator to obtain the respective extracts and stored in a freeze condition at $-18^{\circ} \mathrm{C}$ until used for further analysis.

Quantitative phytochemical estimation of the crude extract: Phytochemical analysis of crude extract of Azadirachta indica A. Juss was carried out using standard quantitative methods as described by Hagerman et al. (2000); Kumaran and Karunakaran (2006); Obdoni and Ochuko (2001). The components analyzed for phytochemicals were phenol, flavonoids, tannins, alkaloids and saponins.

\section{RESULTS AND DISCUSSION}

Growth and yield: The experiment was conducted on growth and yield of tomato cultivation of neem extract and the results on effectiveness of various treatments were described. There was significant increase in the plant height, number of branches and leaf number at all growth stages from 10-90 days in neem extract treatment in comparison to control (Figs. 1-3). Number of buds from 40-80 days, number of flowers from 50-90 days and number of fruits 90-120 were recorded. All measured parameters gave significant differences from their respective controls (Figs. 4-6). Neem aqueous extract showed a promotive effect on shoot lengths $(58.12 \%)$, branches $(32.65 \%)$ leaf numbers $(11.88 \%)$, number of buds $(11.8 \%)$, number of flowers $(14.5 \%)$ and number of fruits $(14.16 \%)$ with increasing time compared to untreated or control ones. The promotive effect could be due to triterpene which acts by delaying the transformation of ammonium nitrogen into nitrate nitrogen as reported by Akhtar (1999). Growth stimulating effect of ten medicinal plant extracts ( $P$. pinatta, $A$. marmelos, A. indica, B. campestris, P. nigrum, E. tirucalli, V. negundu, A. conyzoides, T. patula and Z. jujube) on Lycopersicum esculentum L. have been observed (Pattnaik et al., 2012). Similar experiment carried out by Okunlola and Thomas (2013) showed the effect of A. indica and Piper guineense on the growth and yield of jute under sole and mixed cropping. All growth parameters increased in comparison to control. In another experiment ethanolic extracts of Melia azedarch, Eucalyptus robosta, Sapium sebiferum had no significant influence on growth and development of Soybean seedlings (Wan et al., 2012). Effect of tea seed extracts on growth of beet, mustard, oat and barley were studied. Different concentrations of these extracts increased the growth, yield and biomass of the crops. The growth stimulating effect is not exclusively by its adverse effect on pathogen or by an increase in nutrient uptake. However substances with hormone like properties can stimulate of effect biomass allocation in plants. In addition to hormones, medicinal plant extracts contain saponins and polyphenols which could be the active compounds causing the effect on growth (Anderson, 2010).

Diseases: Because of its fleshy nature, tomato fruit is attacked by a number of insect pests and diseases. Pathogenic diseases develop through soil borne and above ground infections, and, in some instances, are transmitted through insect feeding. Major tomato diseases include those that attack the root system (fusarium wilt, verticiliun wilt, bacterial wilt, rhizoctonia), above -ground stems and foliage (early blight, leaf spot, bacterial canker, late blight), and fruit (bacterial spot, bacterial speck, anthracnose) (Pandey et al., 2006). Thus, the disease control programme is important at each stage of growth (Tomato Diseases and Disorders).

Canker caused by Clavibacter michiganense subsp. michiganense (Cmm), is a serious pathogen of tomatoes which causes serious losses in some tomato plantings. It is often first seen as dark, necrotic lesions at the margins of older leaves. This disease can cause esions or cankers on any portion of the plant, including the fruit, or it can result in a general wilt or decline of the plant (Gleason et al., 1993; Jones et al., 1991). In our field experiment neem reduced canker disease by $50.32 \%$ in comparison to control (Fig. 7). Different combinations of natural treatments could give better effects against bacterial canker (Clavibacter michiganensis subsp. michiganensis) and bacterial speck (Pseudomonas syringae pv. tomato) of tomato such as natural compounds (Tinivella et al., 2009), plant extracts (Hartman et al., 


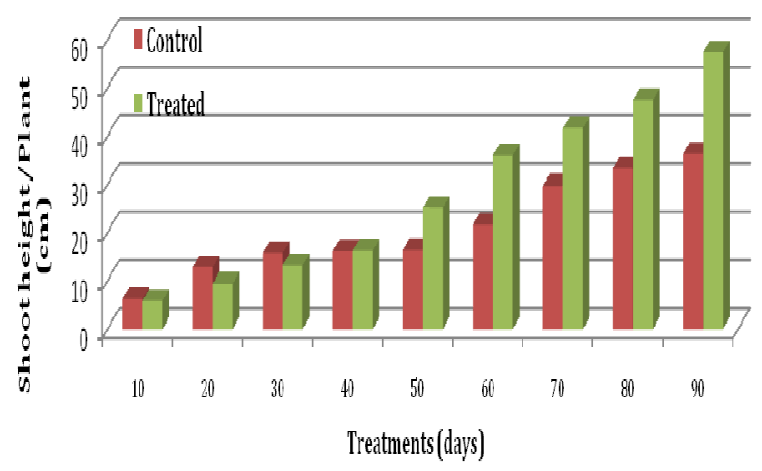

Fig. 1. Effect of A. indica aqueous extract on plant height of L. esculentum.

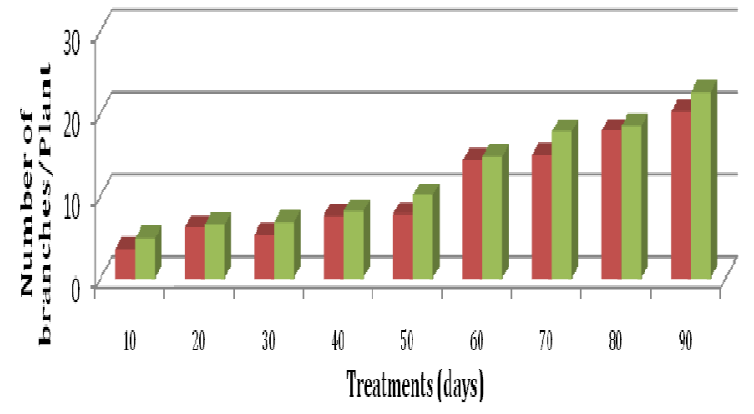

Fig. 3. Effect of A. indica aqueous extract on number of branches of L. esculentum.

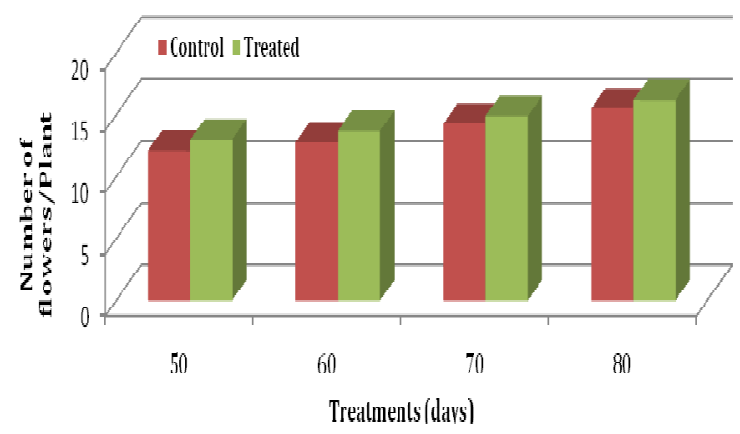

Fig. 5. Effect of A. indica aqueous extract on number flowers of L. Esculentum.

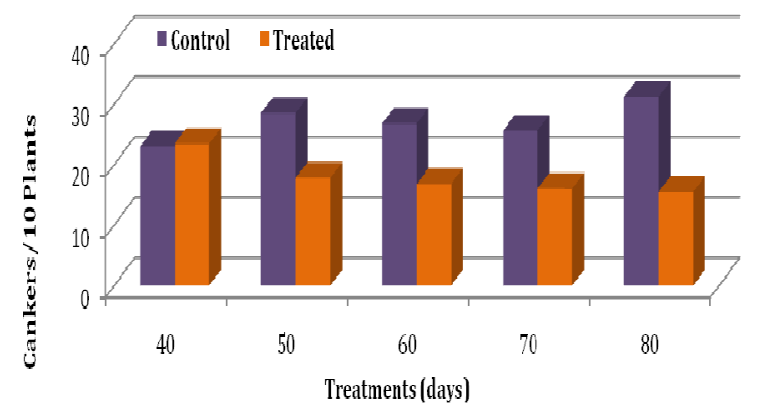

Fig. 7. Effect of A. indica aqueous extract on canker disease of L. esculentum.

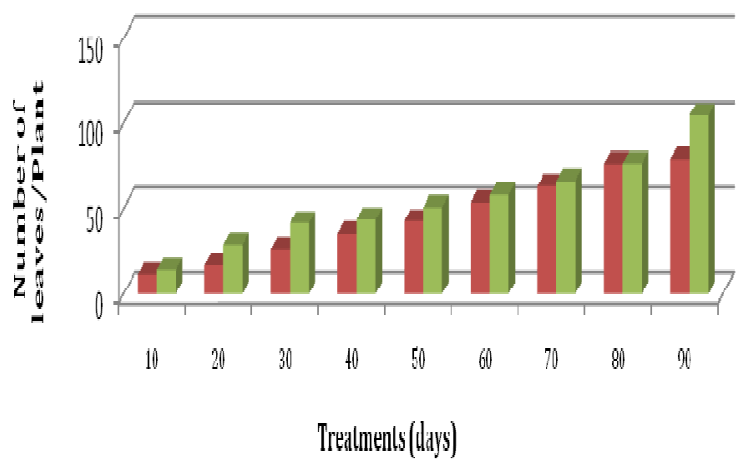

Fig. 2. Effect of $A$. indica aqueous extract on number of leaves of L. esculentum.

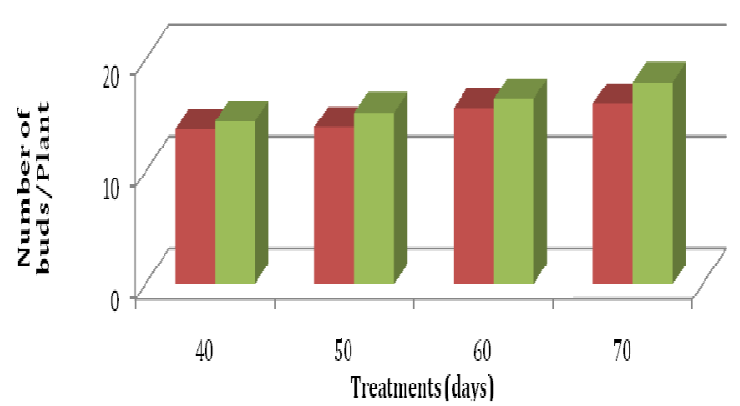

Fig. 4. Effect of A. indica aqueous extract on number of buds of L. esculentum.

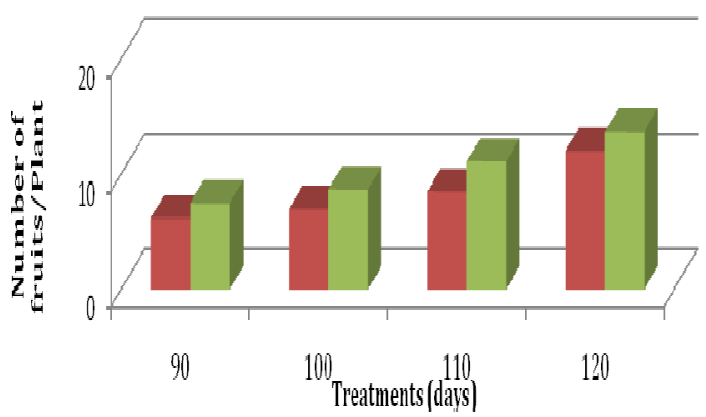

Fig. 6. Effect of A. indica aqueous extract on number fruits of L. esculentum.

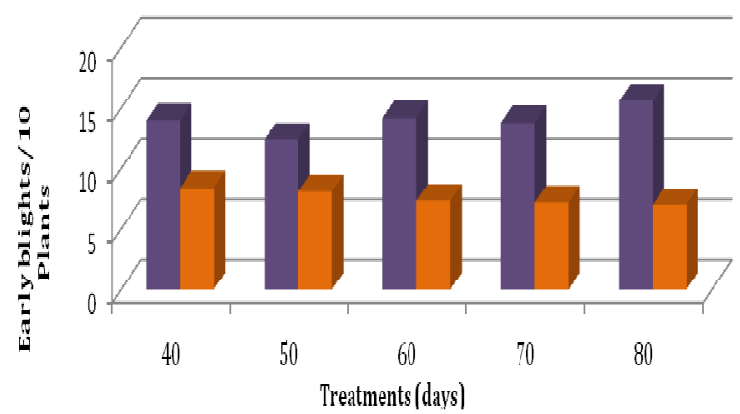

Fig. 8. Effect of A. indica aqueous extract on early blight disease of L. esculentum. 


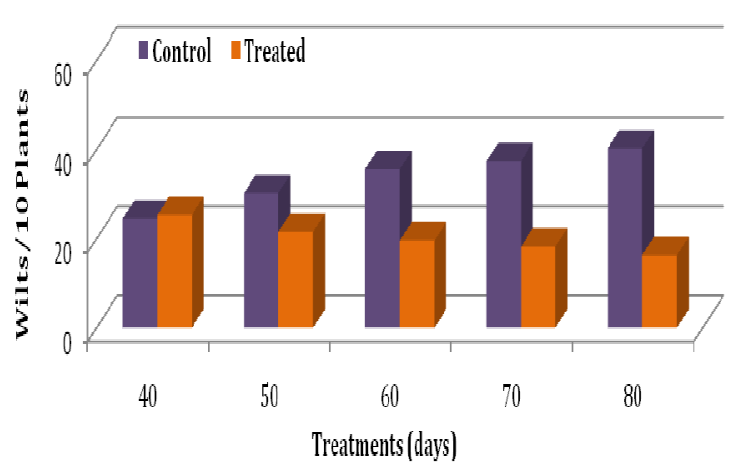

Fig. 9. Effect of $A$. indica aqueous extract on wilt disease of L. esculentum.

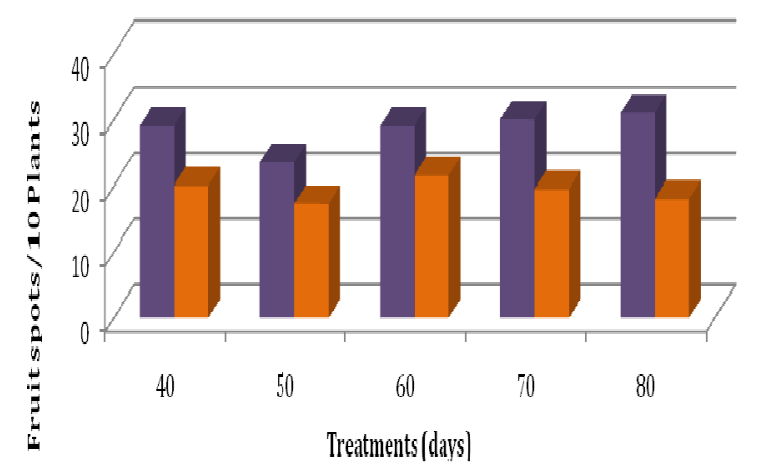

Fig. 11. Effect of A. indica aqueous extract on fruit spot disease of L. esculentum.

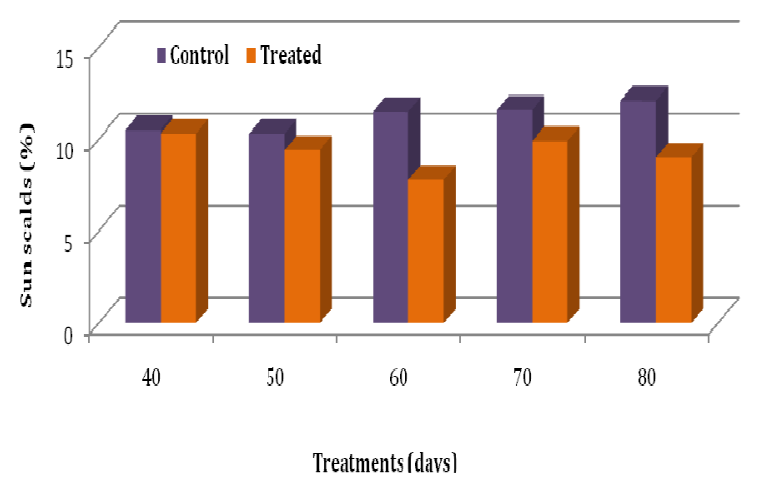

Fig. 13. Effect of A. indica aqueous extract on sun scald disease of $L$. esculentum.

1995), essential oils (Schmitt et al., 2009) and natural acids (Roberts et al., 2006). It was studied that the essential oils from $T$. spicata and $O$. syriacum had the highest inhibitory activity against Clavibacter michiganensis subsp. Michiganensis corresponding to $83.6 \%$ and $82.8 \%$ increase in the zones of inhibition over the control (Soylu et al., 2003).

Early blight caused by the fungus A. solani, is common foliage diseases which first appears in the older leaves and are characterized by irregular shaped brown spots with concentric rings (Arden, 1987; Sunil and Srivastava, 2013).

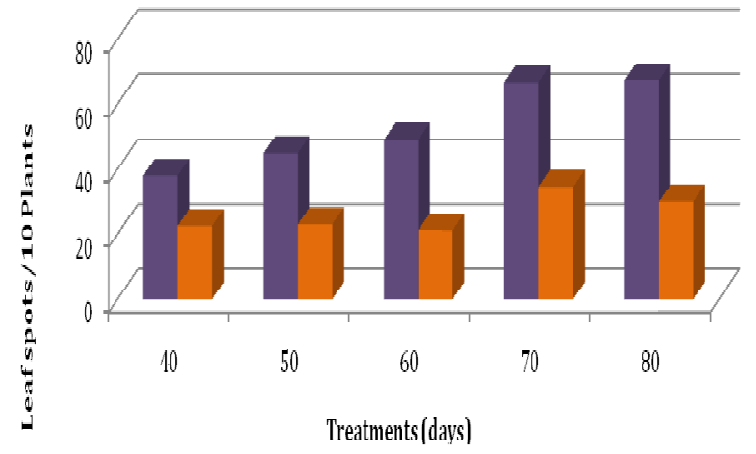

Fig. 10. Effect of A. indica aqueous extract on leaf spot disease of L. esculentum.

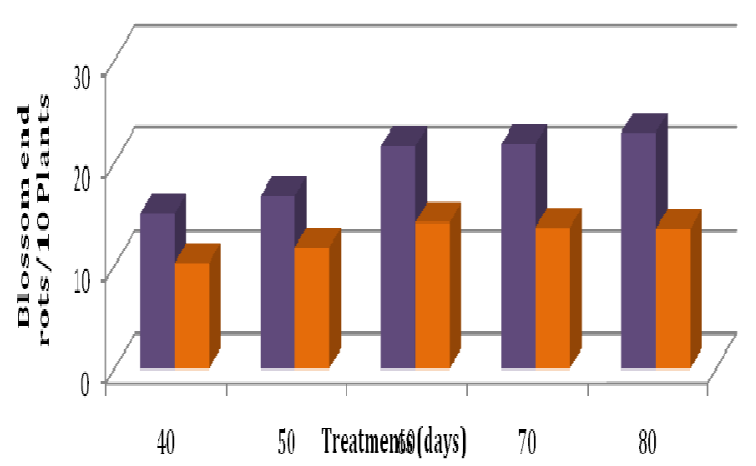

Fig. 12. Effect of A.indica aqueous extract on blossom end rot disease of L. esculentum.

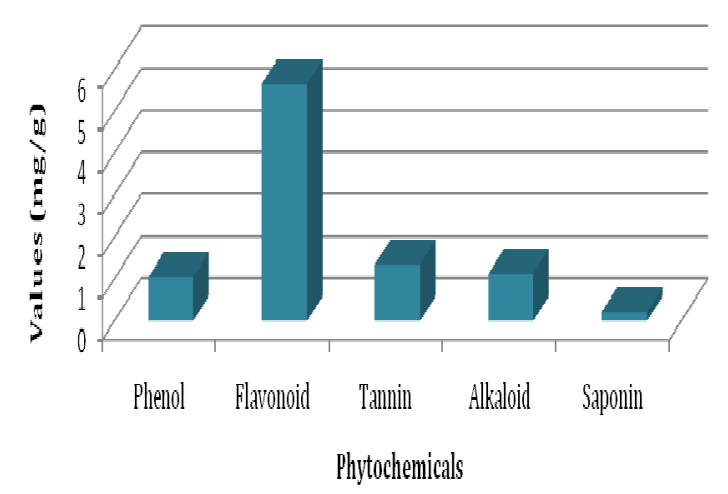

Fig. 14. Phytochemical estimation of A. indica leaves.

These infections often occur near the stem of the tomato fruit. Reported Carrot plants sprayed with sea weed extracts showed less disease due to Alternaria and Botrytis compared to SA and the control (Jayaraj et al., 2008). Previous reports have shown that seaweed extracts can reduce disease and promote plant growth. Jayaraj et al. (2008) reported sea weed evaluated in carrot plants reduced leaf blights caused by Alternaria and Botrytis as effectively as the fungicide chlorothalonil. The result obtained from our investigation showed that the aqueous neem extract act as good antifungal agent by reducing early blight by $55.12 \%$ in 
tomato plant (Fig. 8). Similarly garlic and neem oils have also been shown to be effective in reducing the severity of early blight disease of tomato (Wszelaki and Miller, 2005).

Wilt is caused by the soil borne fungus Fusarium oxysporum f. sp. Lycopersici. The leaf extracts of Azadirachta indica substantially reduced the number of infected leaves and number of lesions on foliage, and curtailed disease development, which in turn, protected flowers and capsules from infection (Enikuomehin, 2005). Similarly our result also showed a positive effect on reducing Fusarium wilt by $59.45 \%$ (Fig. 9). The results obtained from EI-Khalal, 2007; Croxton et al., 2011 who reported that the growth rate of shoot and root was markedly inhibited in tomato seedlings in response to fusarium wilt diseases. Effect of crude extract of neem and neem seed at concentrations ranging from 5-30\% inhibited growth of Fusarium oxysporum the causal agent of tomato wilt (Ogechi et al., 2006). This further strengthens our field experiment on wilt control of tomato by aqueous neem extract.

Leaf spot caused by the fungus Septoria lycopersici which are noticeable by small, circular spots on the upper surface of the lower leaves. Heavily infected leaves turn yellow, wither, and eventually fall off. Reduction of leaf spot disease was observed from $40^{\text {th }}$ day onwards and maximum reduction was observed on $80^{\text {th }}$ day in comparison to control $(55.48 \%$ ) (Fig.10). A study was undertaken to evaluate the effectiveness of 33 plant extracts against leaf spot of ground nut. All treatments including $A$. indica gave considerable reduction in disease incidence (Hussain et al., 2013). Suppression of septorial leaf disease of tomato by aerated compost tea reduced $26.3 \%$ of diseases by foliar spray (Gangaiah et al., 2004). It can be concluded that neem leaf extract was found more effective in comparison to other plants.

Fruit spot caused by Pseudomonas syringae pv. is the most common disease in tomatoes. Spots on tomato fruit are not very deep. They can be cut out and the tomato can be eaten (Reddy et al., 2001). Suppression of bacterial spots of tomato with foliar sprays of compost extract under green house and field condition was investigated. The population of infected leaves was reduced significantly by extracts prepared from cow manure (Jaber Aldahmani et al., 2003). In the present study neem extract treated tomato plants showed significantly better performance over control by 41.93\% (Fig.11).

Blossom end rot which is caused by a calcium deficiency that is related to wide fluctuations in available moisture which can be caused by excessive use of nitrogen. Brownish black spots on the blossom end of the fruits which may gradually increase in size invade the lesion and cause complete rotting of the fruit (Reddy et al., 2001). Reduction in incidence of blossom end rot of tomato by foliar application of plant extract mixed with $\mathrm{Ca}$ and sugar ester reduced the incidence of blossom end rot in comparison to control (Ikeda and Osawa, 1988).
However, neem extract only reduced BER by $40.86 \%$ without any addition of minerals and micro nutrients (Fig.12).

Sunscald appears as light patches on green or ripening fruit. As the patches grow, they may blister and may become grayish-white. Affected sunscald tomatoes can develop black mold (Sunburn or Sunscald-Peppers and Tomatoes). In various studies it was shown that neem based pesticides like neem cake, neem seed kernel extract (NSKE), neem leaf extract, neem oil etc., act as a repellent and antifeedent and its oil is effective against fruit borer (Elshafie and Basedow, 2003). Similar observation was noticed in our experiment where the foliar application of neem leaf extract reduced $25.61 \%$ of sun scald (Fig.13).

Quantitative estimation of phytochemical compounds of neem leaves showed the presence of phenols, flavonoids, tannins, alkaloids and saponins (Fig. 14). These class of compounds independently or in combination may be responsible for the broad range of medicinal properties of neem which exhibit an extra ordinary array of pharmacological activities. A. indica (Indian Neem tree), contains at least 35 biologically active phenolic compounds which are present predominantly in the seeds, leaves and other parts of the neem tree (Mondall et al., 2009; Nahak and Sahu, 2010) are the most active insecticidal ingredients for effective control of leaf spot, fruit spot, blossom end rot and sun scald diseases of Solanum lycopersicum L. (Brahmachari, 2004; Gajalakshmi and Abbasi, 2004). Treatment of some plants with neem aqueous provided a control of many fungal diseases through a metabolic changes in plants including induction of phenol, antioxidant defensive enzymes and phenol accumulation (Paul and Sharma, 2002; Guleria and Kumar, 2006; Aboellil, 2007). The bio-efficacy of neem extract over pathogens can be attributed to the fact that neem has active compounds such as azadirachtin, nimbin, nimbidin, nimbinene and azadirone which are antifungal, antibactrial and anti-insecticidal in nature (Bohra et al., 2006).

\section{Conclusion}

Neem extracts are good alternative to synthetic pesticides because they are easily available, safe to environment, cost effective, non hazardous, natural enemies, have low to moderate mammalian toxicity. Though neem based products have been successfully used for pest control in agriculture since long, the registered neem products for control of pathogens or disease vectors affecting human, still need to be explored. In line with the above findings it is suggested that the further researches on neem should be directed towards identification and quantification of active principles responsible for pest control.

\section{ACKNOWLEDGEMENTS}

The authors are thankful to University Grants Commission, New Delhi, India for financial assistance in the form of 
Rajiv Gandhi National Fellowship (RGNF). We are also thankful to Director, School of Biotechnology, KIIT University, Bhubaneswar, Odisha, India for providing necessary facilities for carrying out the experimental work. Finally we are thankful to Sabitri Nahak for helping in computer work without which preparation of the manuscript would not have been possible.

\section{REFERENCES}

Aba AlKhail, A.A. (2005). Antifungal activity of some extracts against some plant pathogenic fungi. Pakistan J. Biol. Sci., 8(3):413-417.

Abbasi, P.A., Cuppels, D.A. and Lazarovits, G. (2003). Effect of foliar applications of neem oil and fish emulsion on bacterial spot and yield of tomatoes and peppers. Can. J. Plant Pathol., 25: 41-48.

Abd-El-Kareem, F. (2007). Induced resistance in bean plants against root rot and alternaria leaf spot diseases using biotic and abiotic inducers under field conditions. Research Journal of Agriculture and Biological Sciences, 3(6): 767-774.

Aboellil, A.H. (2007). Trilogy, a product of neem (Azadirachta indica) induces resistance in cucumber againstPodosphaera xanthi. Research Journal of Microbiology, 2 (5): 402-414.

Abogharsa, I.A., Saeed M.A. and Buhidma M.S. (2006). Control of fusarium wilt fungus on tomato plant by plant extracts. Ninth Arab Congress of Plant Protection, Damascus, Syria.

Akhtar, M. and Mahmood, I. (1995). Evaluation of a neem based product against root-knot nematode Meloidogyne incognita. Tests of Agrochemicals and Cultivars. Annal. Appl. Biol., 16: 6-7.

Amadioha, A.C. (2000). Controlling rice blast in vitro and in vivo with extracts of Azadirachta indica. Crop Prot., 5: 287-290.

Anderson, M. (2010). Plant growth is stimulated by tea-seed extract: a new natural growth regulator? Hort. Science, 45(12): 1848-1853.

Arden F. Sherf. (1987). Text for septoria leaf spot from: foliar blights of tomato. Department of plant pathology, Cornell University; text for septoria leaf spot from: foliar blights of tomato, V38, 1987, Ohio State University.

Bohra, B., Vyas B.N. and Mistry, K.B. (2006). Ecofriendly management of damping- off in winter vegetables and tobacco using microbial agents and neem formulations. J. Mycol. Pl. Pathol., 36: 178-181.

Brahmachari, G. (2004). Neem- an omnipotent plant: A retrospection. Chem. Biochem., 5: 408-421.

Chaturvedi, R., Razdan, M.K. and Bhojwani, S.S. (2003). Production of haploids of neem (Azadirachta indica A. Juss.) by anther culture. Plant Cell Rep., 21: 531-537.

Croxton, S.D., Foshee, III, W.G., Blythe, E.K., Murphy, J.F. and Sibley, J.L. (2011). Evaluation of selected tempera paints applied to tomatoes to reduce the occurrence of Tomato spotted wilt virus. International Journal of Vegetable Science, 17:177-189.

Deepak, S.A., Oros, G., Sathyanarayana, S.G., Shetty, H.S. and Sashikanth, S. (2007). Antisporulant activity of watery extracts of plants against Sclerospora graminicola causing downy mildew disease of pearl millet. American Journal of Agricultural and Biological Sciences, 2 (1):36-42.
Deepak, S.A., Oros, G., Sathyanarayana, S.G., Shetty, N.P., Shetty, H.S., Sashikanth, S. (2005). Antisporulant activity of leaf extracts of Indian plants against Sclerospora graminicola causing downy mildew disease of pearl millet. Archives of Phytopathology and Plant Protection, 38(1):31-39.

Dubey, R.C., Kumar, H. and Pandey, R.R. (2009). Fungitoxic effect of neem extracts on growth and sclerotial survival of Macrophomina phaseolina in vitro. J. Am. Sci., 5: 17-24.

El-Khallal, S.M. (2007). Induction and modulation of resistance in tomato plants against fusarium wilt disease by bioagent fungi (Arbuscular Mycorrhiza) and/or hormonal elicitors (Jasmonic Acid \& Salicylic Acid): 2-changes in the antioxidant enzymes, phenolic compounds and pathogen related-proteins. Australian Journal of Basic and Applied Science, 1 (4): 717-732.

El-Mougy, N.S., Abd-El-Karem, F., El-Gamal, N.G. and Fotouh, Y.O. (2004). Application of fungicides alternatives for controlling cowpea root rot diseases under greenhouse and field conditions. Egypt. J. Phytopathol., 32: 23-35.

Elshafie, H.A.F. and Basedow, T.H. (2003). The efficacy of different neem preparations for the control of insects damaging potatoes and eggplants in the Sudan. Crop protection, 22: 1015-1021.

Enikuomehin, O.A. (2005). Cercospora leaf spot disease management in sesame (Sesamum indicum L.) with plant extracts. Journal of Tropical Agriculture, 43(1-2): 19-23.

Gajalakshmi, S. and Abbasi, S.A. (2004). Neem leaves as a source of fertilizer cum-pesticide vermicompost. Bioresource Technol., 92: 291-296.

Gangaiah, C., Carey, E. and Tisserat, N.A. (2004). Suppression of Septoria Leaf Spot disease of tomato using aerated compost tea. Kansas State University. ASHS annual meeting. Available on http://www.ashs.org / annual meeting /conference/index.lasso.

Gleason, M.L., Gitaitis, R.D. and Ricker, M.D. (1993). Recent progress in understanding and controlling bacterial canker of tomato in eastern North America. Plant Disease, 77:1069-1076.

Guleria, S. and Kumar, A. (2006). Azadirachta indica leaf extract induces resistance in sesame against Alternaria leaf spot disease. Journal of Cell and Molecular Biology, 5: $81-86$.

Hagerman, A., Muller I. and Makkar, H. (2000). Quantification of tannins in tree foliage. A laboratory manual, Vienna: FAO/IAEA, pp. 4-7.

Hartman, M, Szoboszlai, S. and Kriszt, B. (1995). Biogazdák által alkalmazott növényi kivonatok értékelése laboratóriumi körülmé- nyek között. Növényvédelem, 31 (2): 59-65.

Hussain, B., War, A.R. and Sharma, H.C. (2013). Jasmonic and salicylic acid-induced resistance in sorghum against the stem borer Chilo partellus. Phytoparasitica. pp.1-22.

Ikeda, H. and Osawa, T. (1988). The effects of $\mathrm{NO}_{3} / \mathrm{NH}_{4}$ ratios and temperature of the nutrient solution on growth, yield and blossom end rot incidence in tomato. J. Jpn. Soc. Hort. Sci., 57: 62-69.

Reddy, M.S. Ryu, C.M., Rodríguez-Kábana, R., Dawkins, T. and Kloepper, J.W. (2001). Can Beneficial Bacteria from Auburn Boost Tomato Growth and Yield? www.bashanfoundation.org/reddy/reddyyield.pdf.

Jaber H. Al-Dahmani, Pervaiz A. Abbasi, Sally A. Miller and Harry A.J. Hoitink. (2003). Suppression of bacterial spot of tomato with foliar sprays of compost extracts 
under greenhouse and field conditions. Plant Disease, 87(8): 913-919.

Jayaraj, J.A., Wan, M. and Rahman Punja, Z.K. (2008). Seaweed extract reduces foliar fungal diseases on carrot. Crop Protection, 27:1360-1366.

Jones, J.B., Jones, J.P., Stall, R.E. and Zitter, T.A. (1991). Compendium of tomato diseases. American Phytopathological Society Press. St. Paul, MN.

Kumaran, A. and Karunakaran, R. (2006). Anti oxidant and free radical scavenging activity of an aqueous extracts of Coleus aromaticus. Food chemistry, 97: 109-114.

Mandal, S., Mallicka, N. and Mitraa A. (2009). Salicylic acid induced resistance to Fusarium oxysporum f. sp. lycopersici in tomato. Plant Physiology and Biochemistry, 47(7): 642-649.

Mondall, N.K., Mojumdar, A. Chatterje, S.K., Banerjee, A. Datta J.K. and Gupta, S. (2009). Antifungal activities and chemical characterization of Neem leaf extracts on the growth of some selected fungal species in vitro culture medium. J. Appl. Sci. Environ. Manage., 13(1): 49-53.

Nahak, G. and Sahu, R.K. (2010). Antioxidant activity in bark and roots of Neem (Azadirachta indica) and Mahaneem (Melia azedarach).J of American Sci., 4: 28 -34 .

Obdoni, B. and Ochuko, P. (2001). Phytochemical studies and comparative efficacy of the crude extracts of some homostatic plants in Edo and Delta States of Nigeria. Global J. Pure Appl. Sci., 8: 203-208.

Ogechi, N., Agbenin, Marley, P.S. (2006). In-vitro assay of some plant extracts against Fusarium oxysporum f. Sp. Lycopersici Causal agent of tomato wilt. Journal of Plant Protection Research, 46(3): 215-220.

Okunlola, I.A. and Thomas, I.O. (2013). Effect of mixed cropping and plant extracts on the growth, yield and pest control of jute (Corchorus olitorius L.). Folia Hort., 25 (1): 49-60.

Pandey, A.K., Namgyal, D., Mehdi, M., Mir, M.S. and Shikh, B.A. (2006). A case study: major insect pest associated with different vegetable crops in cold arid region, Ladakh of Jammu and Kashmir. J. Entomol. Res., 30: 169-174.

Panthee, D.R. and Chen, F. (2010). Genomics of fungal disease resistance in tomato. Curr. Genomics, 11: 30-39.

Pattnaik, M., Kar, M. and Sahu, R.K. (2012). Bioefficacy of

some plant extracts on growth parameters and control of diseases in Lycopersicum esculentum. Asian Journal of Plant Science and Research, 2(2):129-142.
Paul, P.K and Sharma, P.D. (2002). Azadirachta indica leaf extract induces resistance in barley against leaf stripe disease. Physiological and Molecular Plant Pathology, 61(1): 3-13

Rauf, B.A. (2000). Seed-borne disease problems of legume crops in Pakistan. Pak. J. Sci. and Industrial Res., 43: 249-254.

Roberts, S.J. (2006). Physical and biological seed treatments for control of bacterial diseases of carrots and brassicas caused by Xanthomonas app., 11th International Conference on Plant Pathogenic Bacteria, Edinburgh, Scotland.

Rojo, F.G., Reynoso, M.M. Sofia M.F. and Torres, A.M. (2007). Biological control by Trichoderma species of Fusarium solani causing peanut brown root rot under field conditions. Crop protection, 26: 549-555.

Schmitt, A., Koch, E., Stephan, D., Kromphardt, C., Jahn, M., Krauthausen, H.J., Forsberg, G., Werner, S., Amein, T., Wright, F. Tinivella, Van der Wolf J. and Groot, S.P.C. (2009). Evaluation of non-chemical seed treatment methods for the control of Phoma valerianellae on lamb`s lettuce seeds. Journal of Plant Diseases and Protection, 116 (5), 200-207.

Soylu, S., Soylu, E.M., Bozkurt, İ.A. and Kaya, A.D. (2003). Antibacterial activities of essential oils from oregano, thyme, rosemary and lavender plants against Pseudomonas savastanoi pv. phaseolicola, the causal agent of halo blight of bean. Ovidius Univ. Ann. Med. Sci. Pharm., 1: 40-44.

Sunil, K. and Srivastava, K. (2013). Screening of tomato genotypes against early blight (Alternaria solani) under field condition. The Bioscan., 8(1): 189-193.

Tinivella, F., Hirata, L.M. Celan, A., Wright, S.A.I., Amein, T., Schmitt, A. Koch, E. Van Der Wolf, J., Groot, S.P.C., Stephan, D. Garibaldi, A. Gullino, M.L. (2009). Control of seed-borne pathogens on legumes by microbial and other alternative seed treatments. Eur. J. Plant Pathol. 123: 139-151.

Vir, D. and Sharma, R.K. (1985). Studies on the fungicidal properties of neem oil. Indian J. Plant Pathol., 3: 241-242.

Wan, J., Xu, J., Yang, M., Yang, Z., Huang, Q. and Zhao, S. (2012). Effects of three plant extracts on growth and development of dodder and soybean and on protective enzymes of host. Legume Genomics and Genetics, 3(2): 8-13.

Wszeaki, A.L., and Miller, S.A. (2005). Determining the efficacy of disease management product in organically -produced tomatoes. Plant Health Progress. Plant Health Progress, (July): 1-7. 